\title{
Recent shrinkage and hydrological response of Hailuogou glacier, a monsoon temperate glacier on the east slope of Mount Gongga, China
}

\author{
LIU Qiao, ${ }^{1,2}$ LIU Shiyin, ${ }^{1}$ ZHANG Yong, ${ }^{1,3}$ WANG Xin, ${ }^{1}$ ZHANG Yingsong, ${ }^{1}$ \\ GUO Wanqin, ${ }^{1} \mathrm{XU}$ Junli $^{1}$ \\ ${ }^{1}$ State Key Laboratory of Cryosphere Sciences, Cold and Arid Regions Environmental and Engineering Research Institute, \\ Chinese Academy of Sciences, 320 Donggang West Road, Lanzhou 730000, China \\ E-mail: liuqiao@imde.ac.cn \\ ${ }^{2}$ Institute of Mountain Hazards and Environment, Chinese Academy of Sciences, Chengdu 610041, China \\ ${ }^{3}$ Graduate School of Environmental Studies, Nagoya University, Nagoya 464-8602, Japan
}

\begin{abstract}
Temperate glaciers are more sensitive to climate changes than polar or continental glaciers, and can drive remarkable runoff variation in local water catchments. Here we present recent glacier shrinkage and runoff change for Hailuogou glacier, a typical monsoon temperate glacier on the east slope of Mount Gongga (Minya Konga), China. The surface area of Hailuogou glacier has decreased by $3.5 \%\left(0.92 \mathrm{~km}^{2}\right.$ ) between 1966 (aerial photographs) and 2007 (ASTER images). Flow measurements at a stream gauge about $500 \mathrm{~m}$ down-glacier commencing in 1994 display a remarkable increase in annual runoff (mostly during July-September) since 1999. Annual runoff over the same period in a nonglacierized but forested subcatchment $\left(9.17 \mathrm{~km}^{2}\right)$ did not experience significant change. By separating the daily rainfall component from the daily total discharge, monthly catchment water-balance series were calculated for the period 1994-2005, which shows an increasing trend of glacier storage loss. We concluded that air-temperature rise (with a trend of $+0.2^{\circ} \mathrm{C}(10 \mathrm{a})^{-1}$ between 1988 and 2005, recorded at nearby weather stations) has had an increased effect on glacier mass loss and river runoff change during the past 20 years.
\end{abstract}

\section{INTRODUCTION}

Relationships between climate-induced glacier change and runoff yield have been the concern of several studies (e.g. Braun and others, 2000; Aizen and others, 2007; Huss and others, 2008; Masiokas and others, 2008; Mernild and others, 2008) and reports (e.g. Bajracharya and others, 2007; Bates and others, 2008). Climate-induced water-resource shortages pose an urgent problem in some arid and glaciermeltwater supplied regions (Kaser and others, 2003), for example in northwest China (Shi and Zhang, 1995; Yao and others, 2004). In some glacierized high-mountain regions exhibiting recent glacier fluctuations due to climate warming, local hydrological and ecological environments are experiencing remarkable changes (e.g. Ruiz and others, 2008; Moore and others, 2009), generally accompanied by a high frequency of natural hazards (Richardson and Reynolds, 2000; Kääb and others, 2005), such as glacier lake outburst floods (Cenderelli and Wohl, 2003; Ng and others, 2007) or glacier-induced debris/mud-flows (Stoffel and Beniston, 2006; Chiarle and others, 2007).

Monsoon temperate (or maritime) glaciers are more active than cold or continental glaciers, and are characterized by high accumulation and ablation and high mass-balance amplitude (Braithwaite and Zhang, 2000; He and others, 2003; Kaser and others, 2006). Braithwaite and Zhang (1999) found that there is a clear relationship between glacier massbalance sensitivity and amplitude. Glaciers in arctic and continental regions (e.g. the high mountains of Asia), with small mass-balance amplitudes, have a low sensitivity, whereas monsoon temperate glaciers have higher sensitivity (Braithwaite and Zhang, 1999), leading to high local hydrological variability with regional climate change.
Monsoon temperate glaciers in China are mainly distributed in the southeastern part of the Qinghai-Xizang (Tibetan) Plateau (Shi and Liu, 2000), with an area of $13200 \mathrm{~km}^{2}$ and accounting for $22.2 \%$ of China's total glacier area (Shi and others, 2008). These glaciers are more sensitive to climatic changes than polar or continental glaciers (Shi and Liu, 2000; Liu and others, 2006). Since the maximum extent during the Little Ice Age, the area covered by monsoon temperate glaciers in China has decreased by $3920 \mathrm{~km}^{2}$ (Su and Shi, 2002). With a decrease in precipitation, glacier retreat will be even faster (Shi and Liu, 2000). During prolonged periods of net mass loss, specific runoff will first increase until the glacier has retreated, then the decrease in glacier area will lead to reduced flow rates (Braun and others, 2000; Jansson and others, 2003).

Most temperate glaciers on Mount Gongga have retreated continuously throughout the 20th century (Su and Shi, 2000). After a relatively slow or stationary retreat of the terminus during the 1970s, Hailuogou glacier underwent accelerated recession in response to increasing climatic warming since the mid-1980s ( $\mathrm{Li}$ and others, in press). Heim (1936) first reported the glaciers in Mount Gongga after his expedition to Sichuan, China, in 1930. Based on his description of the terminal position and by comparing aerial photos and field investigations, Su and others (1994) and He and others (2008) concluded that Hailuogou glacier retreated $1150 \mathrm{~m}$ during the period 1930-66, $200 \mathrm{~m}$ during 1966-83, $147 \mathrm{~m}$ during 1983-89, $274 \mathrm{~m}$ during 1990-2004 and $50 \mathrm{~m}$ during 2004-06. The first systematic Glacier Inventory of China in the Gongga mountain ranges was based on topographic maps (Pu, 1994, p. 117-129) derived from aerial photographs acquired in 1960 by the Chinese 


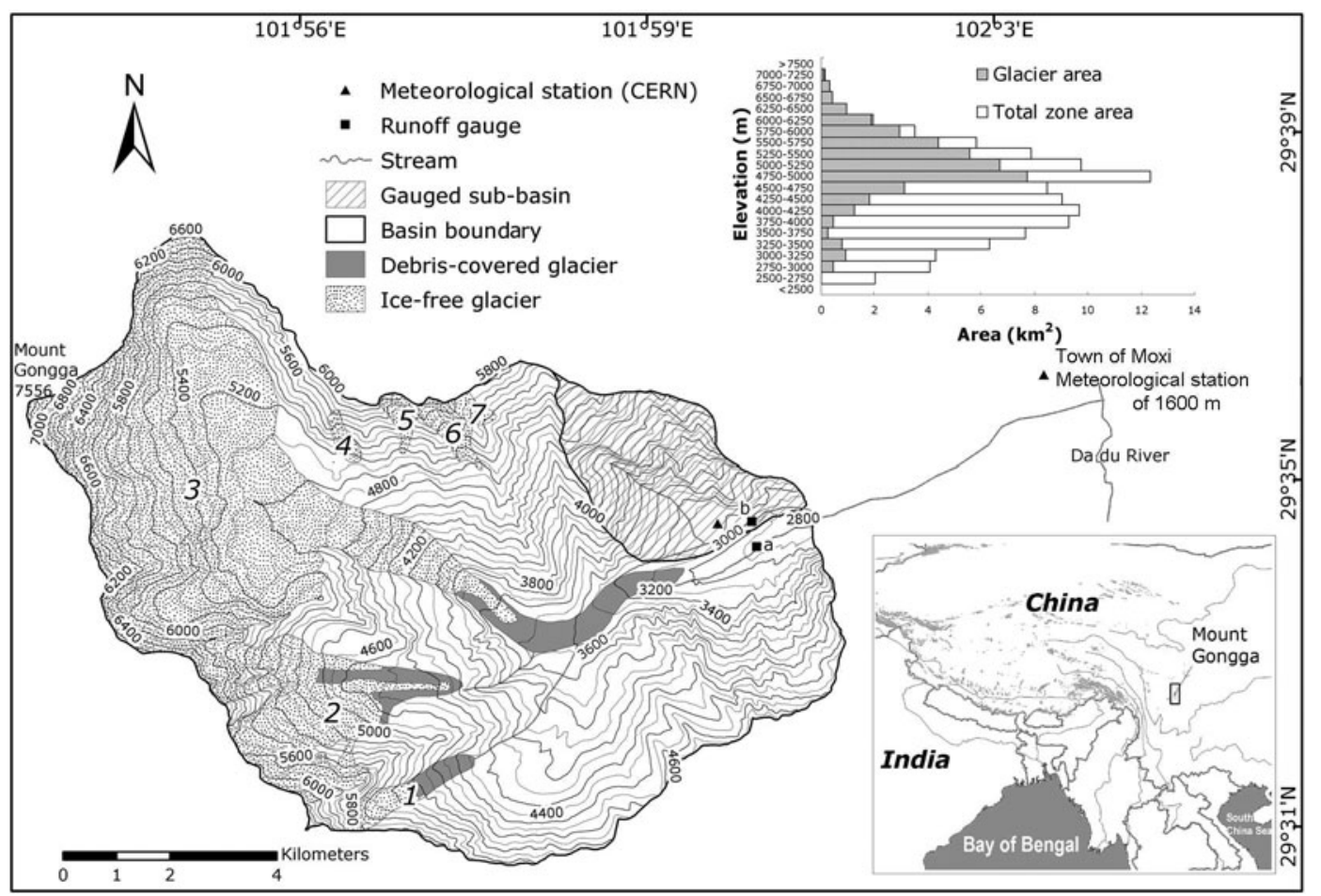

Fig. 1. Map showing catchment location (inset) and glacier distribution (glacier extent is based on the First Glacier Inventory of China and 1994 Landsat TM). Black squares $a$ and b are runoff gauge stations for the HLG and HBLG catchments respectively. Black triangle shows location of meteorological station monitored by the Chinese Ecological Research Network (CERN). Contours show elevation (ma.s. I.) at $100 \mathrm{~m}$ intervals.

military geodetic service. Mass-balance measurements conducted during 1990-98 showed that Hailuogou glacier had an average mean specific mass balance of $-6.41 \mathrm{~m}$ during that time (Zhang and others, 2001). However, these measurements were conducted only in the lower ablation areas. In the accumulation areas, the available data are much sparser because of the steep topography and difficulty in accessing the glacier accumulation areas.

On the catchment scale, no previous studies have assessed glacier change impacts on local hydrological regimes in this monsoon-controlled environment. This study presents the result of a remote-sensing based investigation of the recent recession of seven glaciers in a catchment located on the east slope of Mount Gongga. We analysed the variation over a decade of runoff from the glacierized catchment, by comparing it with runoff of an adjacent nonglacierized catchment. We then calculated the glacier catchment hydrological balance, relating it to recent changes in climatic conditions and glacier mass loss.

\section{STUDY AREA}

Mount Gongga (or Minya Konga; 29.6 $6^{\circ}$, $101.9^{\circ} \mathrm{E}$ ) is located in the centre of the Hengduan Shan on the southeastern edge of the Tibetan Plateau. There are 74 glaciers distributed around Mount Gongga (Pu, 1994, p. 117-129), which is within the Indo-Chinese region of monsoons prevailing in the summer (Aizen and Loktionova, 1994). The glaciers are noted as summer-accumulation type (Su and others, 1996; Shi and Liu, 2000; Xie and others, 2001).

Hailuogou glacier is the largest valley glacier on the east slope of Mount Gongga. It is labelled 'glacier No. 3' (Shi and others, 2008) in the Hailuogou catchment (HLG), above the town of Moxi (Fig. 1). In 1994 it was $12.16 \mathrm{~km}$ long and 250-1200 m wide, with an area of $24.83 \mathrm{~km}^{2}$. It comprises a cirque-shaped accumulation area from 7556 to $4980 \mathrm{~m}$ a.s.l., a nearly $1300 \mathrm{~m}$ high icefall from 4980 to $3700 \mathrm{~m}$ a.s.l., and a glacier tongue stretching into forest at $2990 \mathrm{~m}$ a.s.l. The six other glaciers in the HLG catchment are much smaller (Table 1).

Table 1. Geomorphologic characterization of seven glaciers in the HLG catchment. Glacier extent is based on 1994 Landsat TM image, DEM is based on 1989 topographic map (see Table 3)

\begin{tabular}{|c|c|c|c|c|c|c|c|}
\hline & No. 1 & No. 2 & No. $3 *$ & No. 4 & No. 5 & No. 6 & No. 7 \\
\hline Elevation range (m a.s.I.) & $4282-5476$ & $4184-6360$ & $2990-7556$ & $5122-5885$ & $5152-6120$ & 4934-6120 & 5344-5972 \\
\hline Length $(\mathrm{km})$ & 2.22 & 3.95 & 12.16 & 1.05 & 1.18 & 1.60 & 0.74 \\
\hline Slope $(\min / \operatorname{mean} / \max )\left({ }^{\circ}\right)$ & $5 / 33 / 74$ & $0 / 35 / 77$ & $0 / 30 / 77$ & $25 / 46 / 63$ & $1.6 / 47 / 75$ & $0 / 73 / 47$ & $2 / 36 / 61$ \\
\hline
\end{tabular}

*Glacier No. 3 is Hailuogou glacier. 
Table 2. Main characterizations of the HLG and HBLG catchments

\begin{tabular}{lcc}
\hline & HLG & HBLG \\
\hline Total area $\left(\mathrm{km}^{2}\right)$ & 94.75 & 9.17 \\
Glacierized area $\left(\mathrm{km}^{2}\right)$ & 34.67 & 0 \\
Mean altitude (ma.s.I.) & 4797 & 3849 \\
Gauge altitude (ma.s.I.) & 2755 & 2823 \\
Highest point (ma.s.I.) & 7556 & 5452 \\
Mean slope $\left({ }^{\circ}\right)$ & 36.6 & 39.9 \\
Mean annual discharge, $Q\left(10^{6} \mathrm{~m}^{3} ; 1994-2006\right)$ & 363.52 & 6.68 \\
Mean annual temperature $\left({ }^{\circ} \mathrm{C} ; 1^{1988-2005)}\right.$ & 4.1 & \\
\hline
\end{tabular}

The HLG catchment altitude ranges from 2756 to $7556 \mathrm{~m}$, with a mean elevation of $4714 \mathrm{~m}$. It covers an area of $94.75 \mathrm{~km}^{2}$, of which $34.67 \mathrm{~km}^{2}(36.6 \%)$ was glacierized in 1994. The non-glacierized area of the catchment is mainly forested by Faber's Fir (Abies fabri Craib; Shen and others, 2004). In addition to this highly glacierized catchment, a small non-glacierized but forested catchment, the Huangbengliugou catchment (HBLG) northeast of Hailuogou glacier ('Gauged sub-basin' in Fig. 1), is also hydro-analysed in this study. The basic geographical and hydrometeorological characteristics of the two studied catchments are listed in Table 2.

\section{DATA AND METHODS}

\section{Glacier inventory}

Within the working group of the Second Glacier Inventory of China, we have recently used new-generation remote sensors such as the Advanced Spaceborne Thermal Emission and Reflection Radiometer (ASTER) and the Landsat Thematic Mapper/Enhanced Thematic Mapper Plus (TM/ETM+) to identify glacier changes in many areas. However, most images of Mount Gongga suffer from snow, shadow and cloud contamination. As a validation and extension of remote-sensing methods, we carried out detailed GPS measurements in 2008, which covered the lower ablation areas of Hailuogou glacier (Fig. 2a). The measurements were conducted using real-time kinematic (RTK) GPS technology. Similar fieldwork was also carried out at other glaciers in China (e.g. Xiao Dongkemadi glacier (Shangguan and others, 2008)).

The area and boundaries of glaciers in the HLG catchment were derived from topographic maps of 1966 and 1989, Landsat images of 1975 and 1994, and ASTER images of 2007 (Table 3). The raw L1A ASTER images were a

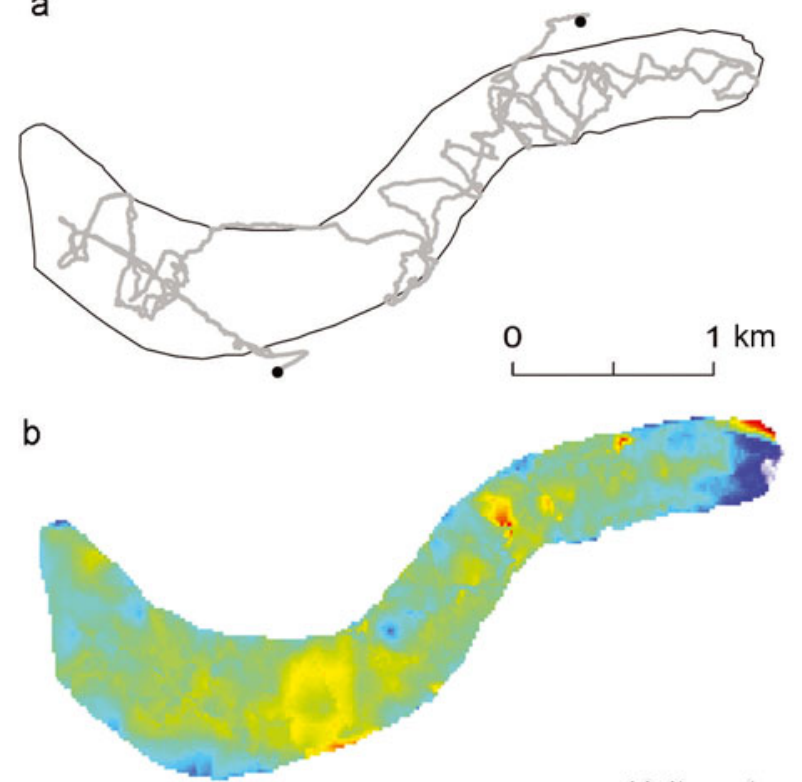

Unit: meter

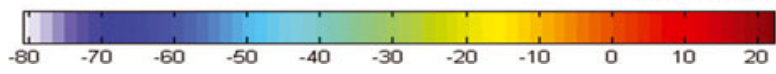

Fig. 2. (a) RTK-GPS measurement tracks (grey points) with base reference points (dark points) and (b) DEM difference elevation changes in the lower ablation area of Hailuogou glacier tongue.

orthorectified using ENVI software. Ground-control points were collected from the 1989 topographic map identified on ASTER images. A digital elevation model (DEM) based on the 1989 topographic map was used to make a topographic correction for ASTER images data. GPS survey data define the 2008 outline of the Hailuogou glacier tongue, and were used to generate a DEM of the glacier surface with a pixel resolution of $15 \mathrm{~m}$ and vertical accuracy of $\pm 0.19 \mathrm{~m}$ (Zhang and others, 2010). Using the GPS-derived DEM-2008 minus the topographic-map derived DEM-1989, the elevation changes in the lower ablation area of Hailuogou glacier are shown in Figure $2 b$.

All datasets were spatially referenced to the local Universal Transverse Mercator coordinate system (UTM zone $47 \mathrm{~N}$, WGS84) and were incorporated as grids into a Geographical Information System database for analysis. Glaciers were visually interpreted and outlines were manually delineated. The 2007 outline of the Hailuogou glacier tongue was shape-adjusted by GPS points from 2008 fieldwork. Error estimation is quantified based on the image spatial resolution or map scale $(1: 100000$ and $1: 50000$ are equated respectively to spatial resolutions of 30 and

Table 3. Topographic maps and satellite remote-sensing data

\begin{tabular}{lccc}
\hline Date* & Satellite sensor/map & Source & $\begin{array}{c}\text { Spatial resolution/ } \\
\text { map scale }\end{array}$ \\
\hline Dec 1966 & & Chinese military geodetic service & $1: 100000$ \\
Nov 1989 & Topographic map & Chinese military geodetic service & $1: 50000$ \\
4 Oct 1975 & Topographic map & USGS $/$ NASA & $57 \mathrm{~m}$ \\
5 Sept 1994 & Landsat MSS & USGS/NASA & $28.5 \mathrm{~m}$ \\
15 Dec 2007 & Landsat TM & NASA/METI & $15 \mathrm{~m}$
\end{tabular}

*Date for topographic maps is the aerial photo date. 'Multispectral scanner. WUnited States Geological Survey. `Japan's Ministry of Economy, Trade and Industry. 


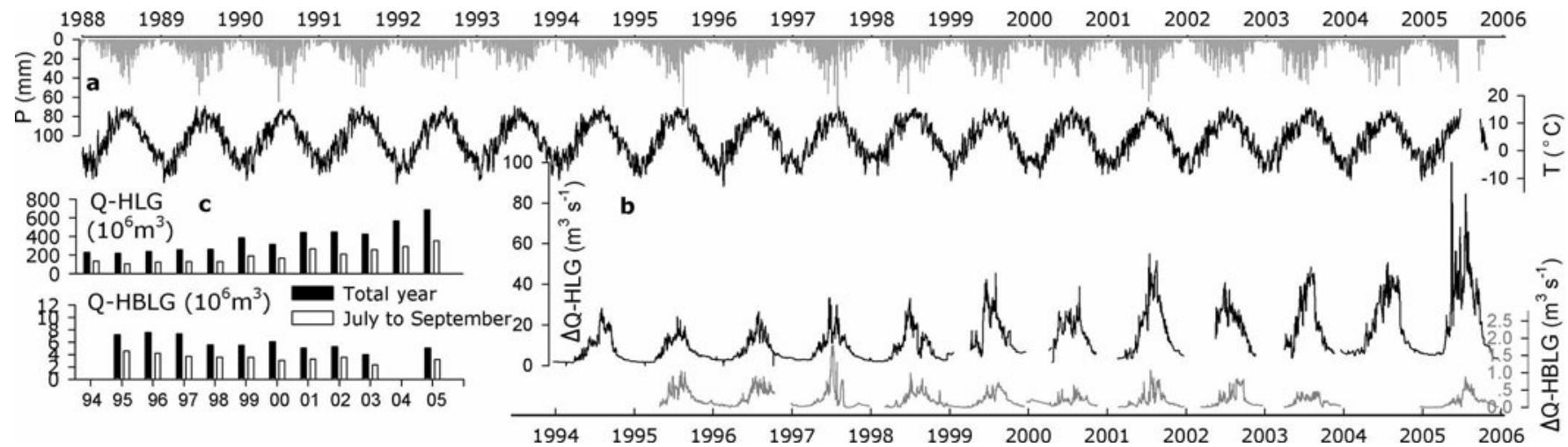

Fig. 3. Raw data recorded by the CERN showing evolution of (a) daily mean air temperature and precipitation at $3000 \mathrm{~m}$, (b) mean discharge rate from HLG (black) and HBLG (grey) catchments and (c) annual (black bars) and summer (July-September; white bars) discharge.

$15 \mathrm{~m}$ in pixel size). To calculate changes between two images, an average spatial resolution of these two maps is assumed for error determination.

\section{Hydro-climatic observations}

Meteorological and hydrological data were measured by Gongga Alpine Ecosystem Observation and Research Station (GAEORS), Chinese Ecological Research Network (CERN; http://www.cern.ac.cn). Two meteorological stations (Fig. 1) were established at 3000 and 1600 ma.s.l. close to the glaciers and have been monitored since 1988 and 1991 respectively. Precipitation, temperature, evaporation, humidity, radiation, etc., were collected at these stations. Temperature and precipitation lapse rates were calculated between 1600 and $3000 \mathrm{~m}$ a.s.l. The total area of the catchment was divided into a glacierized catchment (the HLG catchment) and a lower non-glacierized catchment (the HBLG catchment). Runoff of the HLG and HBLG catchments was gauged from 1994 and 1995 respectively, to 2006. We present the continuous daily streamflow data (Fig. 3) for the glacierized HLG catchment for the period 1994-2005 and for the nonglacierized HBLG catchment for the period 1995-2005. Climatic records from the $3000 \mathrm{~m}$ meteorological station from 1988 to 2005, including mean daily air temperature and precipitation, are also shown in Figure 3.

\section{Catchment water balance}

A remarkable increasing trend in runoff from the HLG catchment is shown in Figure 3c. The water balance of this glacierized catchment was calculated to show how glacier mass loss contributes to runoff. The elements of water balance for a watershed depend upon watershed characteristics and processes. The usual formulation of the waterbalance equation for a glacierized catchment is

$$
P-E-R-\Delta G=\eta,
$$

where $P$ is precipitation input from snow and rain, $E$ is evaporation/sublimation output, $R$ is runoff, $\Delta G$ is change in water storage with the catchment from glacier and groundwater and $\eta$ is the balance discrepancy (error term).

Mark and Seltzer (2003) assumed that evaporation and condensation over the glacier surface are zero or cancel each other out and that groundwater discharge is negligible. In monsoonal temperate conditions over the glacier, net evaporation and condensation is negligible. However, evapotranspiration (ET) from the forested non-glacierized region should be reassessed in the water-balance calculation.
According to a modelling result of Cheng and Guirong (2003), mean monthly ET is about $20 \%$ of precipitation. In the HLG catchment, precipitation was regularly observed at the $3000 \mathrm{~m}$ weather station, but the observation excludes the horizontal precipitation, a component recently estimated by Cheng and others (2002) to comprise about $7-10 \%$ of annual precipitation in this region. High horizontal precipitation and condensation, dew and hoar-frost in the forest area reduce the errors to a certain extent, without taking into account ET in the water-balance calculation. Loss to the groundwater system and liquid water storage in the glacier system is not considered significant. This error was small compared to the observed precipitation, glacier- and snowmelt and runoff.

Neglecting ET, liquid water storage within the glacier system and groundwater, semiquantification of the contribution of glacier meltwater to the runoff is achieved by separating the daily rainfall component, $P$, from the daily total discharge, $Q$, observed at the gauge site. Based on the method of Mark and Seltzer (2003), a basic water-balance model with monthly discharge from the HLG glacierized catchment and total monthly precipitation were used to compute the change in glacier storage from 1994 to 2005. The change in monthly glacier storage, $\Delta G$, is given by

$$
\Delta G=\frac{\sum_{i=1}^{10} P_{i} S_{i}}{\sum S_{i}}-Q_{\mathrm{h}},
$$

where $P_{i}(\mathrm{~mm})$ is the total monthly precipitation over the elevation band $i(i=1-10), S_{i}\left(\mathrm{~mm}^{2}\right)$ is the area of $i$, and $Q_{\mathrm{h}}$ ( $\mathrm{mm}$ w.e.) is depth calculated from the discharge rate, $\Delta Q$ $\left(\mathrm{m}^{3} \mathrm{~s}^{-1}\right)$, over the specific time interval ( $\sim 1$ month here) and normalized by the area of the glacierized catchment.

To calculate $P_{i}$ for each elevation band, the catchment (2755-7556 ma.s.l.) was divided into ten elevation zones from 3000 to $7500 \mathrm{~m}$, spacing at $500 \mathrm{~m}$. Generally, mountain precipitation increases to a maximum at a transition height, then declines with increasing elevation. The transition height is about $3000 \mathrm{~m}$ in the Eastern Himalaya, and higher in the Karakoram mountains (Barry, 2008). However, Cheng (1996) reported that a maximum precipitation at about $3000 \mathrm{~m}$ (or higher) does not seem applicable in our study region. Annual precipitation continues to increase with elevation increase (Fig. 4a). Precipitation lapse rate was calculated monthly based on the 1600 and $3000 \mathrm{~m}$ meteorological station records. Using these monthly lapse rates, the precipitation of the total basin was then the area-weighted sum of the 

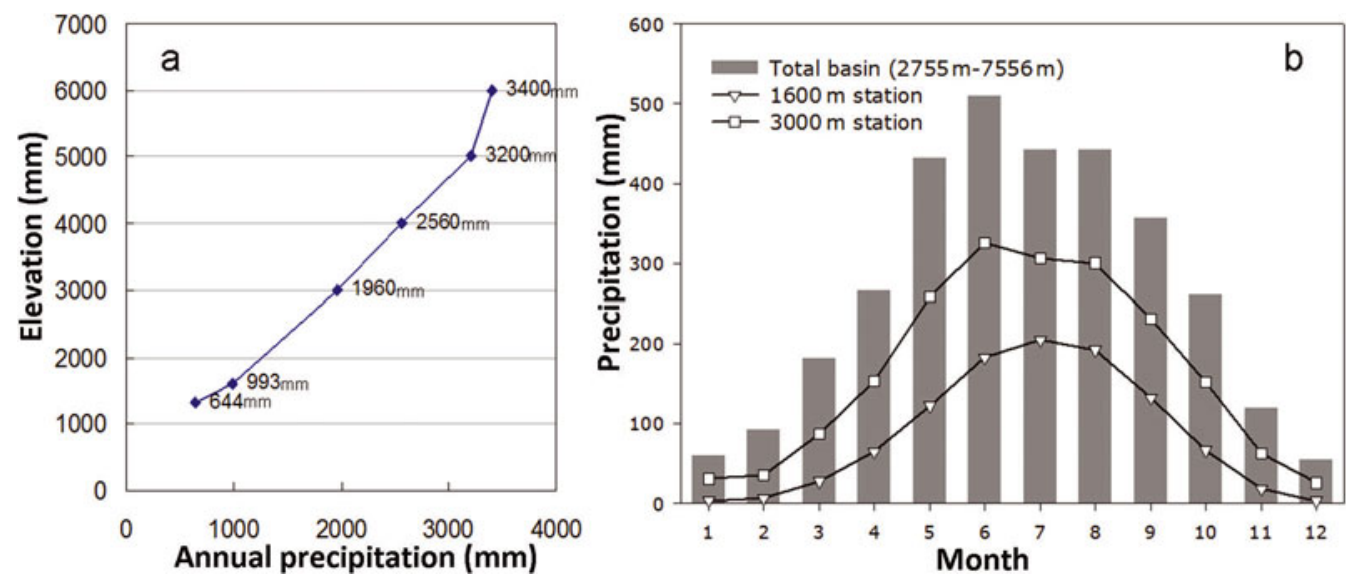

Fig. 4. (a) Annual precipitation variation with elevation according to the results of Cheng (1996). (b) Calculated average monthly precipitation (1994-2005) over the total catchment, and precipitation at 1600 and $3000 \mathrm{~m}$.

precipitation over each elevation band. Figure $4 \mathrm{~b}$ shows the calculated monthly precipitation for the total basin, as an average value from 1994 to 2005.

\section{RESULTS}

\section{Glacier changes}

Total glacier area in the HLG catchment decreased by $2.9 \mathrm{~km}^{2}(7.8 \%)$, from $36.9 \mathrm{~km}^{2}$ in 1966 to $34.0 \mathrm{~km}^{2}$ in 2007. In particular, small glaciers (especially those on south-facing slopes) show a significant shrinkage (Fig. 5; Table 4). For instance, the area of glacier No. 4 decreased by $73.8 \%$ during the study period. Conversely, the change in area of larger glaciers, with sufficient accumulation area at high elevation, is less pronounced. The surface area of Hailuogou glacier decreased by only $0.92 \mathrm{~km}^{2}(3.6 \%)$ during our study period.

The terminus retreats of Hailuogou glacier were $295 \pm 60,252 \pm 45$ and $181 \pm 23 \mathrm{~m}$ for the periods 1966-75, 1975-94 and 1994-2007 respectively. Our results agree well with those of Su and others (1994) and He and others (2008), which were based mostly on field investigations. The agreement is better in recent years, since the spatial resolution of the sensors has been improved (Fig. 6).

For glacier ice thinning, Zhang and others (2009) present recent ice-velocity and elevation changes over the ablation area of Hailuogou glacier. They indicate that the mean rate

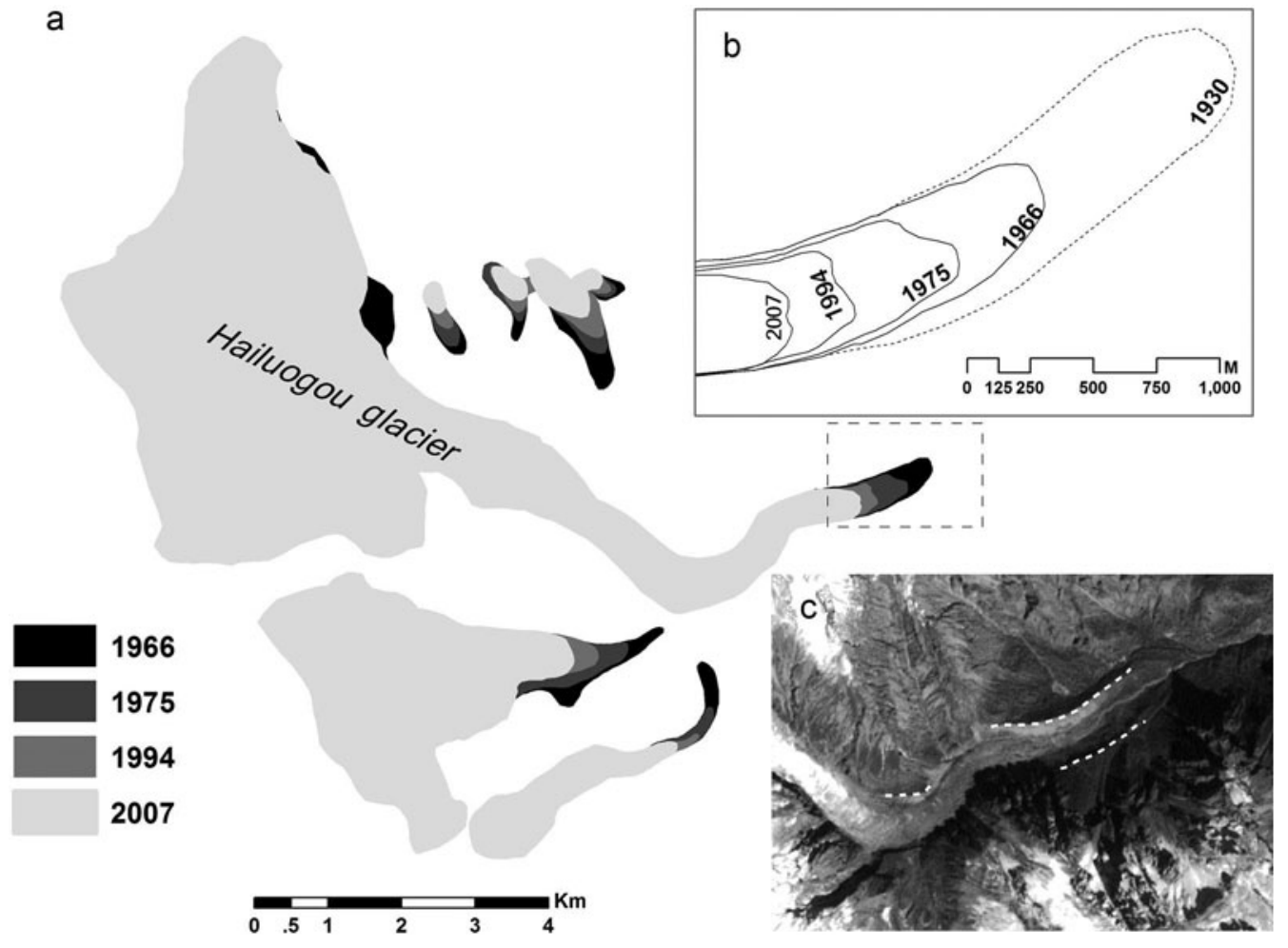

Fig. 5. (a) Surface-area changes of glaciers in the HLG catchment, 1966-2007. (b) Retreat of Hailuogou glacier terminus since 1930; the 1930 outline is based on He and others (2008) from Heim (1936). (c) Band 1 of ASTER images (15 m resolution) in 2007 showing Hailuogou glacier terminus, and trimlines (white dashed) showing glacier shrinking. 


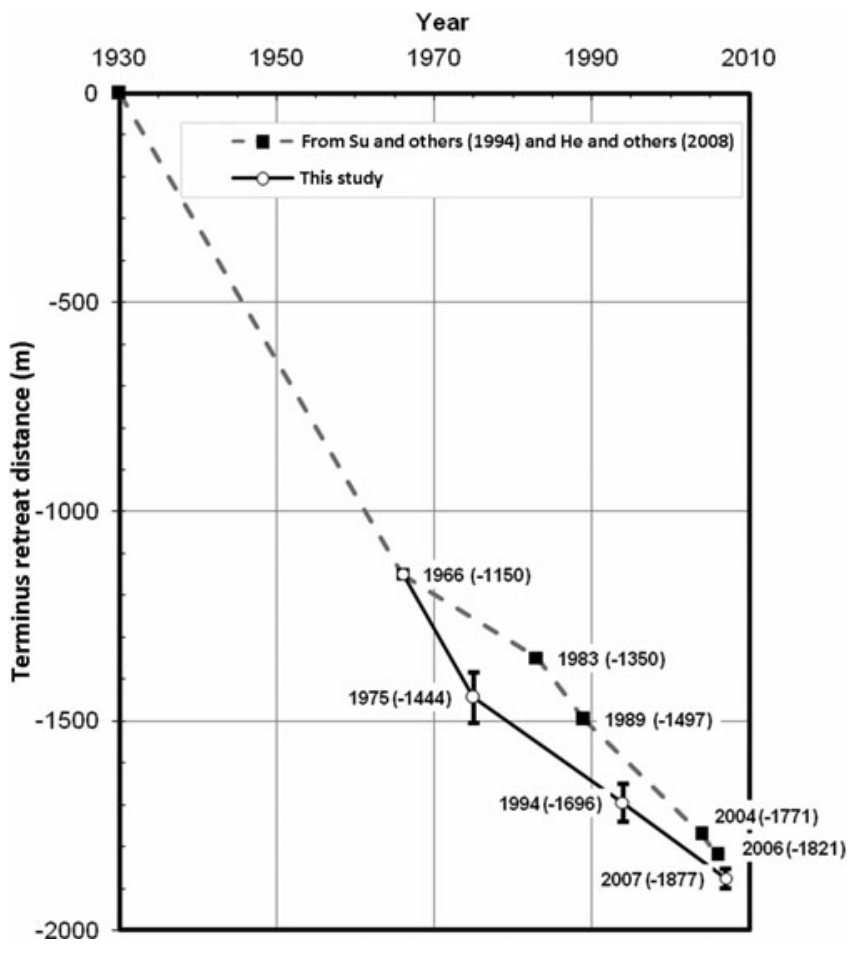

Fig. 6. Terminus retreat distance history since 1930 based on remote sensing and results of previous studies.

of surface elevation change over the ablation area for the 43 years $1966-2009$ is $-1.1 \pm 0.4 \mathrm{ma}^{-1}$; since 1989 , glacier thinning has significantly accelerated. The thinning rate increases from 1966 to 2008. In the lower reaches, net glacier thinning as a fraction of the total thickness is larger than glacier area loss as a fraction of total glacier area (Fig. 2b)

\section{Changes in climatic conditions and runoff}

As indicated by Figure 7 , based on the record from the $3000 \mathrm{~m}$ meteorological station, mean daily air temperature and minimum temperature show significant increases from 1988 to 2005 , at rates of $+0.2^{\circ} \mathrm{C}(10 \mathrm{a})^{-1}$ and $+0.4^{\circ} \mathrm{C}(10 \mathrm{a})^{-1}$ respectively. The mean daily diurnal air-temperature range decreased by $-0.4^{\circ} \mathrm{C}(10 \mathrm{a})^{-1}$.

Data presented in Figure $3 \mathrm{~b}$ indicate that runoff of the HLG catchment shows a continuously increasing trend from 1994 to 2005, while for the HBLG catchment (non-glacierized) there is a slightly decreasing trend. These trends can be easily recognized from the total annual and summer (July-September) runoff variations (Fig. 3c). Annual discharge in the HLG catchment shows a dramatic increase from $232.4 \times 10^{6} \mathrm{~m}^{3}$
(1994) to $684.5 \times 10^{6} \mathrm{~m}^{3}$ (2007). In particular, total discharge during the summer also exhibited a significantly increasing trend during 1994-2005. The remarkably warm summer in 1998 did not lead to a significant increase in runoff. It is possible that higher temperatures in 1998 were offset by lower precipitation (Fig. 7d). A significant increase occurred in 1999, probably due to the global extreme climate event of 1997/98 (Parker and Horton, 1999), which is also represented in Figure $7 \mathrm{a}$ and $\mathrm{b}$.

\section{Changes in water balance in the glacierized catchment}

For the HLG catchment, glacier storage was calculated monthly from 1994 to 2005 based on Equation (1) (Fig. 8). Basin precipitation is the only component showing no significant trend over this period, whereas the change in glacier storage leads to continuously rising discharge amounts. The change in glacier storage, $\Delta G$, provides an estimate of the mean monthly contribution of glacier melt to stream discharge. Positive values of $\Delta G$ represent storage gain (net accumulation), and negative values represent storage loss (net melt) (Mark and Seltzer, 2003). Net melting usually occurs during the ablation season despite the catchment experiencing high precipitation in summer (Xie and others, 2001). From Figure 7, extremely high precipitation during summer 1997 induced positive storage gain: calculated $\Delta G$ was positive during the whole year. Since 1999, however, consecutive negative $\Delta G$ values have occurred, with a maximum glacier storage loss of $1209 \mathrm{~mm}$ in August 2003.

\section{DISCUSSION}

The difference between the glacierized and non-glacierized catchments is that the runoff derived from the non-glacierized catchment is precipitation-dominated while the glacierized catchment is energy-dominated (Chen and Ohmura, 1990). The main contributions to runoff in the catchments are glacier- or snowmelt and rainfall. Of a mean annual precipitation of $1956 \mathrm{~mm}$ from 1988 to 2005, an average of $79.9 \%$ is concentrated in the ablation season (May-October) and $43.9 \%$ in the summer season (July-September) (Fig. 9a). Due to the summer-monsoon dominated climatic conditions (concurrence of ablation and precipitation) on Mount Gongga, the HLG and HBLG catchments have similar annual runoff distribution patterns (Fig. 9b). Over the whole ablation season, in terms of volume, the total discharges for the HLG and HBLG catchments were $306.58 \times 10^{6}$ and $5.26 \times 10^{6} \mathrm{~m}^{3}$ respectively, accounting for about $80 \%$ and $82 \%$ of the mean annual discharges of $363.52 \times 10^{6}$ and

Table 4. Glacier area change since $1966\left(\mathrm{~km}^{2}\right)$

\begin{tabular}{|c|c|c|c|c|c|c|c|c|c|}
\hline Year & Error & No. 1 & No. 2 & No. 3 & No. 4 & No. 5 & No. 6 & No. 7 & Sum \\
\hline 1966 & \pm 0.0009 & 1.6980 & 7.9857 & 25.6493 & 0.2570 & 0.3274 & 0.8299 & 0.1634 & 36.9106 \\
\hline 1975 & \pm 0.0036 & 1.5563 & 7.7684 & 25.0195 & 0.2014 & 0.2867 & 0.6030 & 0.1237 & 35.5588 \\
\hline 1994 & \pm 0.0009 & 1.4651 & 7.4572 & 24.8357 & 0.1211 & 0.1975 & 0.5023 & 0.0945 & 34.6735 \\
\hline 2007 & \pm 0.0002 & 1.4313 & 7.2984 & 24.7335 & 0.0673 & 0.1025 & 0.3369 & 0.0614 & 34.0313 \\
\hline Area shrinkage (1966-2007) $\left(\mathrm{km}^{2}\right)$ & \pm 0.0005 & 0.2667 & 0.6873 & 0.9159 & 0.1896 & 0.2249 & 0.4929 & 0.1020 & 2.8794 \\
\hline
\end{tabular}



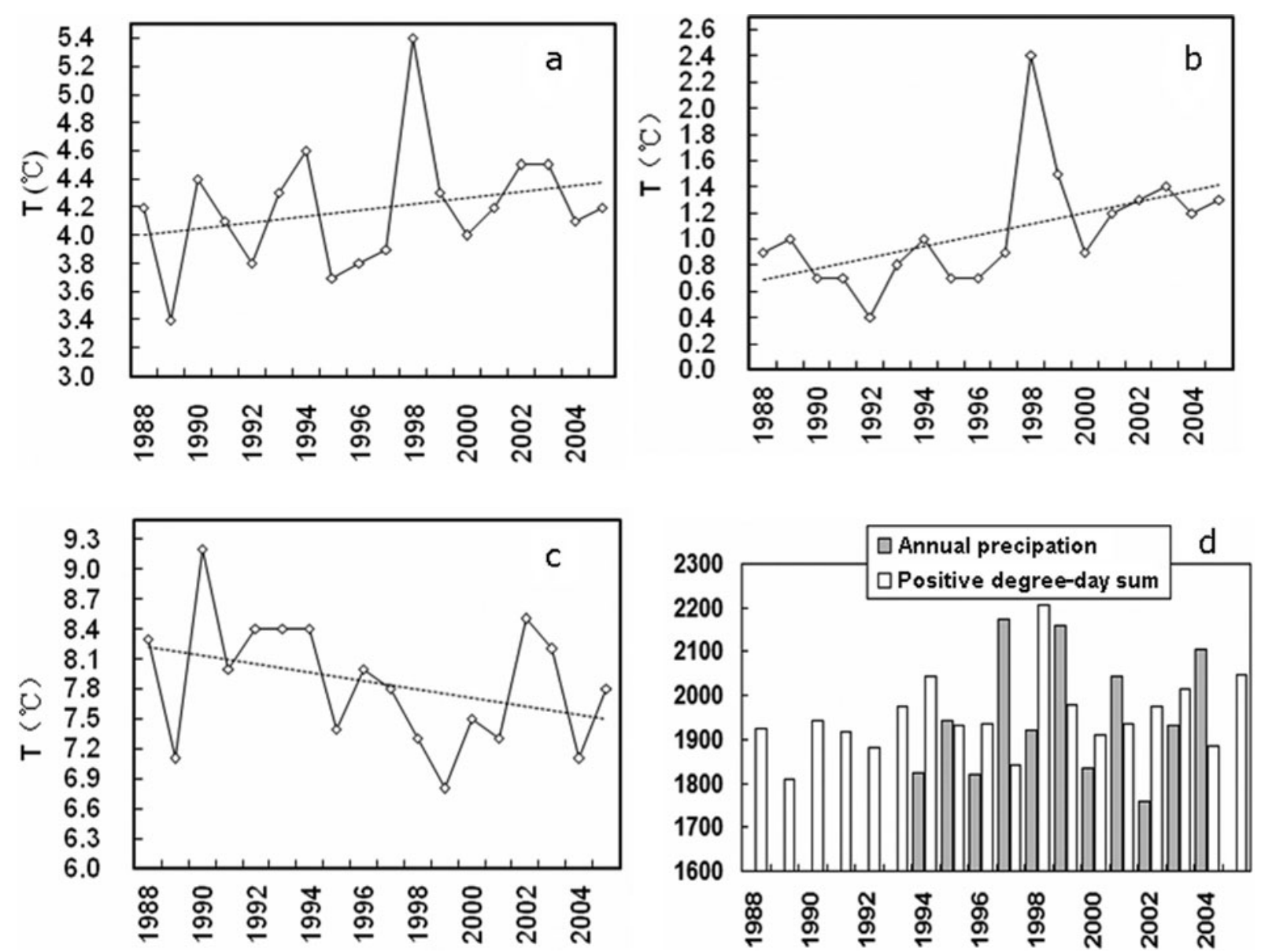

Fig. 7. Variations of (a) mean daily air temperature, (b) mean daily minimum temperature, (c) mean daily diurnal range of air temperature and (d) positive degree-day sum $\left({ }^{\circ} \mathrm{C}\right.$ ) at the $3000 \mathrm{~m}$ meteorological station $(1988-2005)$ and calculated annual precipitation (mm) for the HLG catchment (1994-2004), based on the 3000 m meteorological station data (1988-2005).

$6.68 \times 10^{6} \mathrm{~m}^{3}$ respectively. A slightly larger offset $(\sim 1$ month) between maximum precipitation and runoff of the HBLG catchment (see Fig. 9a) indicates that the water conservation function of the forest is significantly more evident in the non-glacierized catchment than in the glacierized catchment.

We found interannual changes in the water-balance terms as presented in Figure 10 (changes in evaporation and/or sublimation and groundwater were neglected). For missing measurements of runoff during some winters between 1998 and 2003, we interpolate by considering a mean discharge proportion of the annual value for each month. During the calculation period (1994-2004), cumulative loss of glacier storage was $5.93 \mathrm{~m}$ w.e. (6.59 $\mathrm{m}$ ice).

Ice elevations from DEMs show highly accelerated ice thinning in the lower ablation area of Hailuogou glacier in recent years (Zhang and others, 2009). Ice thinning in the lower part of the ablation area is the main glacier shrinking process, compared with terminus retreat (1.5\%) and surface area decrease $(3.5 \%)$. The thinning accounts for $\sim 30 \%$ of local ice thickness (an average of $125 \mathrm{~m}$ measured in 1994; Huang and others, 1996). Considering that the thinning rate

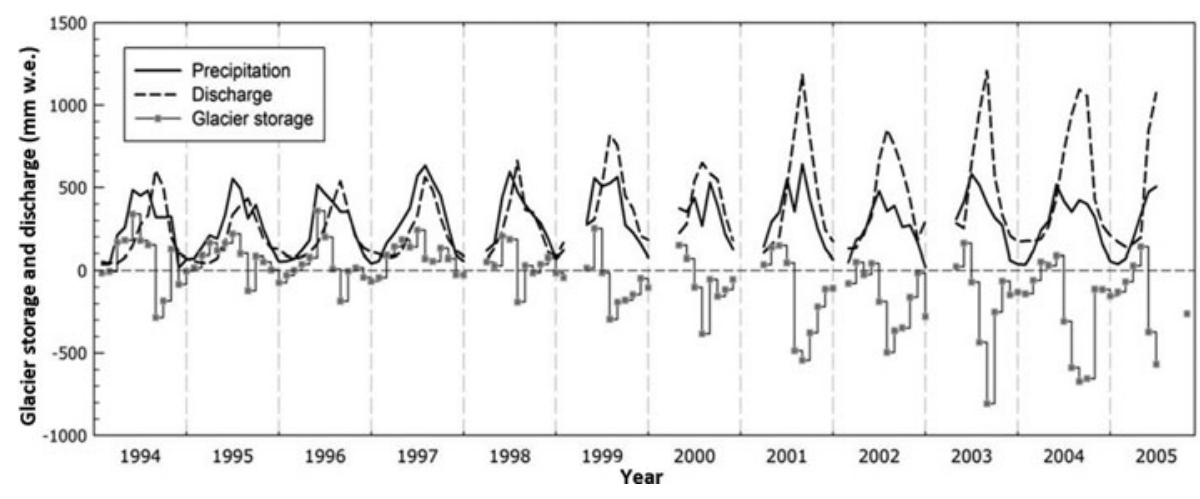

Fig. 8. Monthly glacier storage and discharge, 1994-2005. 

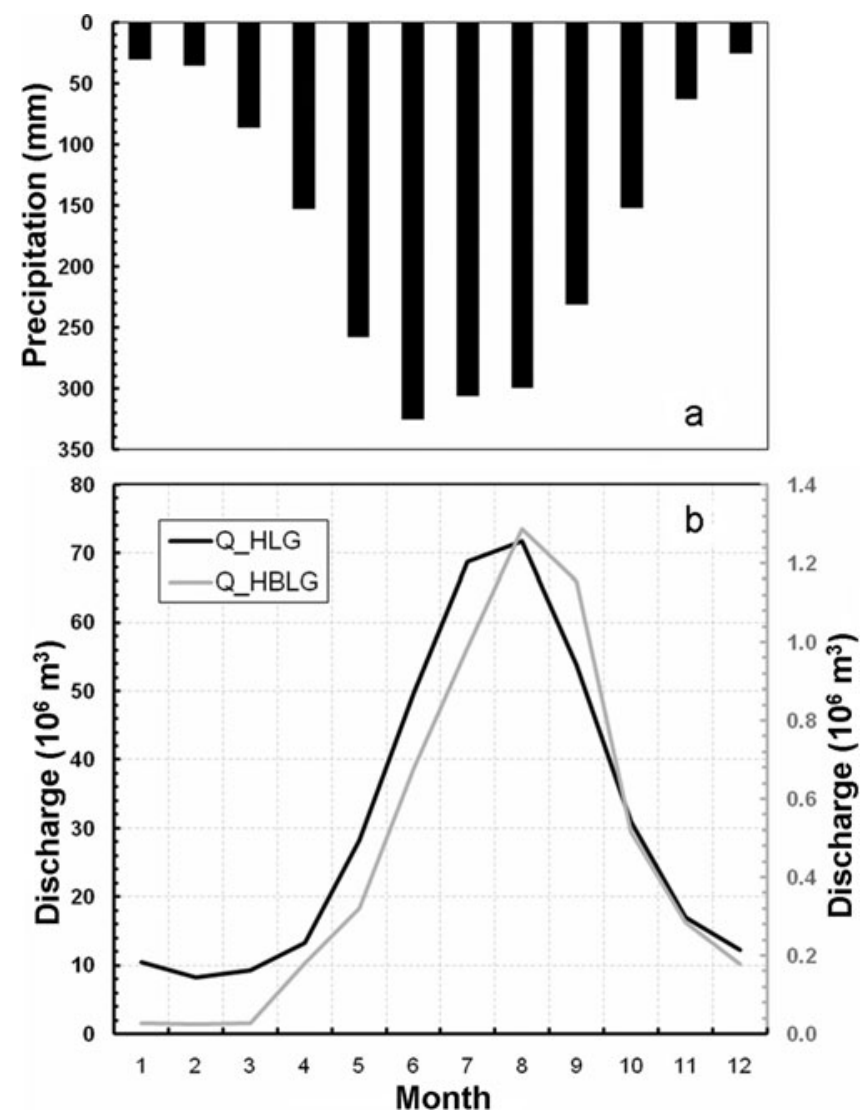

Fig. 9. Intra-annual distribution of (a) precipitation and (b) monthly total discharge of HLG (dark curve) and HBLG (grey curve) catchments, averaged over the period 1994-2005.

in the upper part of Hailuogou glacier was less than $-1.1 \pm 0.4 \mathrm{~m} \mathrm{a}^{-1}$ (1966-2009) but has accelerated in recent years (Zhang and others, 2010), we assume the total glacier thinning rate was $\sim 0.5 \pm 0.4$ to $0.7 \pm 0.4 \mathrm{ma}^{-1}$ during our water-balance calculation period, 1994-2004. That is, the mean total glacier elevation has decreased by $\sim 5-7 \mathrm{~m}$. This result compares well with that of the water-balance approach (thinning of $6.59 \mathrm{mice}$ ) and indicates that our method of calculating water balance without considering changes in evaporation and/or sublimation and groundwater is probably acceptable.

Given no glacier-wide mass-balance monitoring networks (ablation stakes have been drilled only in the lower ablation part of the glacier), we are still investigating modelling approaches to reconstruct the mass-balance history of Hailuogou glacier. Since the glacier meltwater stream has been well documented since 1994, a hydrological method will probably be our first consideration to reconstruct glacier mass balance of the HLG catchment. Such model results will be compared with the geodetic method (interannual mass loss determined by DEMs; Cox and March, 2004) and may also be validated by specific ablation observations in the ablation area.

The long-term monitoring programme of the CERN has produced a comprehensive database which assists the study of global warming impacts on the hydrology of high alpine environments. The trend towards more negative glacier mass balance makes it necessary to continue this monitoring and modelling effort in order to assess the consequences of glacier mass changes on runoff yield and flood potential.

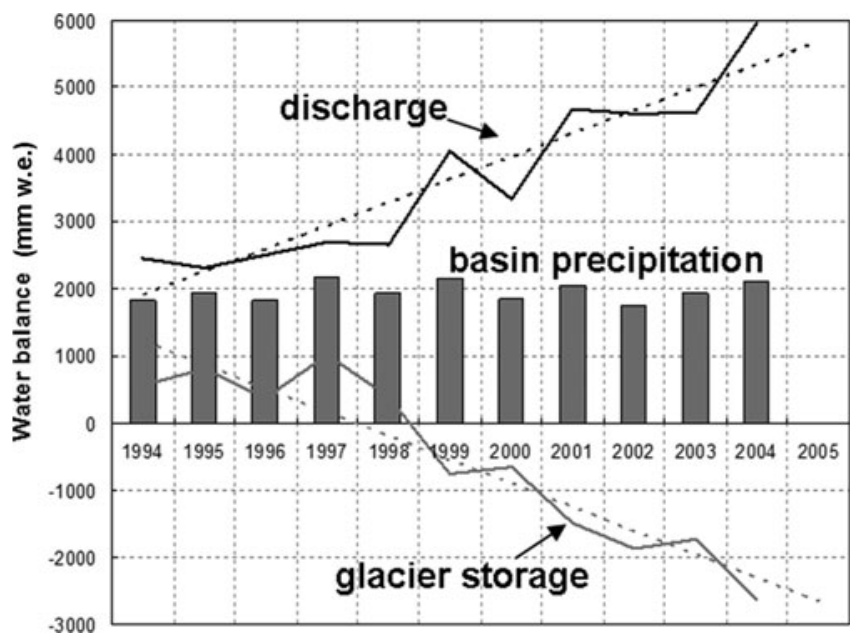

Fig. 10. Interannual change in glacier storage, precipitation and discharge, 1994-2005.

\section{SUMMARY}

Topographic maps, Landsat and ASTER images, combined with detailed RTK-GPS measurements, were used to identify extent and length changes of glaciers in the Hailuogou catchment since 1966.

During the past 20 years (1988-2008), air temperature in the HLG catchment underwent an increasing trend of $+0.2^{\circ} \mathrm{C}(10 \mathrm{a})^{-1}$, whereas a comparatively steady precipitation trend was observed. Temperature changes, rather than precipitation variability, are probably the controlling factor of glacier mass balance in the HLG catchment. Small glaciers have lost most of their areas (73.8\% maximum) due to increasing air temperature in recent decades, and some small glaciers will probably vanish within a few years. Glacier thinning is more marked than changes of glacier area and length, and we can confirm that the main glacier mass loss process is ice thinning.

Remarkable mass loss in the glacierized catchment of HLG leads to variations in runoff for the two catchments. The glacierized HLG catchment exhibits a significant increasing trend in annual and summer runoff, while the non-glacierized HBLG catchment did not experience such significant change.

Glacier storage in the HLG catchment was calculated monthly by separating the daily rainfall component from the daily total discharge. We estimate a thinning rate of $0.5 \pm 0.4$ to $0.7 \pm 0.4 \mathrm{~m} \mathrm{a}^{-1}$ (1994-2004) for the whole area of Hailuogou glacier. We calculated the glacierized catchment water balance using a hydrological method for the same period. Both these approaches result in nearly the same value for glacier mass loss (in terms of ice thinning, $5-7 \mathrm{~m}$ using the geodetic method and $6.59 \mathrm{~m}$ using the hydrological method).

\section{ACKNOWLEDGEMENTS}

Helpful reviews of this paper were provided by two anonymous reviewers and we greatly appreciate manuscript improvement suggestions from T.H. Jacka and T. Scambos. We thank the Gongga Alpine Ecosystem Observation and Research Station, CERN, China, for hydroclimatic data collection and field assistance. This work was funded by 
the Major State Basic Research Development Program of China (973 Program) (2007CB411506) and the Innovation Project of the Chinese Academy of Sciences (Kzcx2-yw301). In addition, we acknowledge grants from the National Natural Science Foundation of China (grant Nos. 40801030 and 40801025) and the National Basic Work Program of Chinese MST (Glacier Inventory of China II, grant No. 2006FY110200). Zhao Jingdong, Li Xiangying, Li Gang and others assisted in the field.

\section{REFERENCES}

Aizen, V.B. and H. Loktionova. 1994. The existing conditions of the southeastern Tibet glacier. In Xie, Z. and V.M. Kotlyakov, eds. Glaciers and environment in the Qinghai-Xizang (Tibet) Plateau (I) - the Gongga Mountain: reports on the Sino-Russian Joint Glaciological Expedition. Beijing and New York, Science Press, 1-28.

Aizen, V.B., E.M. Aizen and V.A. Kuzmichenok. 2007. Glaciers and hydrological changes in the Tien Shan: simulation and prediction. Environ. Res. Lett., 2(4), 045019. (10.1088/17489326/2/4/045019.)

Bajracharya, S.R., P.K. Mool and B. Shrestha. 2007. Impact of climate change on Himalayan glaciers and glacial lakes: case studies on GLOF and associated hazards in Nepal and Bhutan. Kathmandu, International Centre for Integrated Mountain Development and United Nations Environment Programme Regional Office, Asia and the Pacific. (ICIMOD Publication 169.)

Barry, R.G. 2008. Mountain weather and climate. Third edition. Cambridge, etc., Cambridge University Press.

Bates, B., Z.W. Kundzewicz, S. Wu and J. Palutikof. 2008. Climate change and water. Geneva, Intergovernmental Panel on Climate Change. (Technical Paper 6.)

Braithwaite, R.J. and Y. Zhang. 1999. Modelling changes in glacier mass balance that may occur as a result of climate changes. Geogr. Ann., 81A(4), 489-496.

Braithwaite, R.J. and Y. Zhang. 2000. Sensitivity of mass balance of five Swiss glaciers to temperature changes assessed by tuning a degree-day model. J. Glaciol., 46(152), 7-14.

Braun, L.N., M. Weber and M. Schulz. 2000. Consequences of climate change for runoff from Alpine regions. Ann. Glaciol., 31, 19-25.

Cenderelli, D.A. and E.E. Wohl. 2003. Flow hydraulics and geomorphic effects of glacial-lake outburst floods in the Mount Everest region, Nepal. Earth Surf. Process. Landf., 28(4), 385-407.

Chen, J.Y. and A. Ohmura. 1990. On the influence of Alpine glaciers on runoff. IAHS Publ. 193 (Symposium at Lausanne 1990 - Hydrology in Mountainous Regions I), 117-125.

Cheng, G. 1996. Exploration of precipitation features on extra-high zone of Mt Gongga. [Mt. Res.], 14(3), 177-182. [In Chinese with English summary.]

Cheng, G. and C. Guirong. 2003. Study on evapotranspiration simulation of sub-alpine forest area in Gongga Mountain. [Adv. Wat. Sci.], 14(5), 617-621. [In Chinese with English summary.]

Cheng, G., Y. Xinxiao and Z. Yutao. 2002. The hydrological cycle and its mathematical models of forest ecosystem in mountains. Beijing, Science Press.

Chiarle, M., S. Iannotti, G. Mortara and P. Deline. 2007. Recent debris flow occurrences associated with glaciers in the Alps. Global Planet. Change, 56(1-2), 123-136.

Cox, L.H. and R.S. March. 2004. Comparison of geodetic and glaciological mass-balance techniques, Gulkana Glacier, Alaska, USA. J. Glaciol., 50(170), 363-370.

He, Y., Z. Zhang, W.H. Theakstone, T. Chen, T. Yao and H. Pang. 2003. Changing features of the climate and glaciers in China's monsoonal temperate glacier region. J. Geophys. Res., 108(D17), 4530. (10.1029/2002JD003365.)
He, Y. and 7 others. 2008. Changes of the Hailuogou Glacier, Mt Gongga, China, against the background of global warming in the last several decades. J. China Univ. Geosci., 19(3), 271-281.

Heim, A. 1936. The glaciation and solifluction of Minya Gongkar. Geogr. J., 87(5), 444-454.

Huang, M., M. Wang, G. Song, G. Li and Y. Shen. 1996. Hydraulic effects in the ablation area of the Hailuogou Glacier. J. Glaciol. Geocryol., 18, Special Issue, 46-50. [In Chinese with English summary.]

Huss, M., D. Farinotti, A. Bauder and M. Funk. 2008. Modelling runoff from highly glacierized alpine drainage basins in a changing climate. Hydrol. Process., 22(19), 3888-3902.

Jansson, P., R. Hock and T. Schneider. 2003. The concept of glacier storage: a review. J. Hydrol., 282(1-4), 116-129.

Kääb, A., J.M. Reynolds and W. Haeberli. 2005. Glacier and permafrost hazards in high mountains. In Huber, U.M., H.K.M. Bugmann and M.A. Reasoner, eds. Global change and mountain regions: an overview of current knowledge. Dordrecht, etc., Kluwer Academic Publishers, 225-234. (Advances in Global Change Research 23.)

Kaser, G., I. Juen, C. Georges, J. Gomez and W. Tamayo. 2003. The impact of glaciers on the runoff and the reconstruction of mass balance history from hydrological data in the tropical Cordillera Blanca, Peru. J. Hydrol., 282(1-4), 130-144.

Kaser, G., J.G. Cogley, M.B. Dyurgerov, M.F. Meier and A. Ohmura. 2006. Mass balance of glaciers and ice caps: consensus estimates for 1961-2004. Geophys. Res. Lett., 33(19), L19501. (10.1029/2006GL027511.)

$\mathrm{Li}, \mathrm{Z}$. and 11 others. In press. Changes of the Hailuogou glacier, Mt Gongga, China, against the background of climate change during the Holocene. Quat. Int. (10.1016/ j.quaint.2008.09.005.)

Liu, S., Y. Ding, J. Li, D. Shangguan and Y. Zhang. 2006. Glaciers in response to recent climate warming in western China. Quat. Sci., 26(5), 762-771. [In Chinese with English summary.]

Mark, B.G. and G.O. Seltzer. 2003. Tropical glacier meltwater contribution to stream discharge: a case study in the Cordillera Blanca, Peru. J. Glaciol., 49(165), 271-282.

Masiokas, M.H., R. Villalba, B.H. Luckman, M.E. Lascano, S. Delgado and P. Stepanek. 2008. 20th-century glacier recession and regional hydroclimatic changes in northwestern Patagonia. Global Planet. Change, 60(1-2), 85-100.

Mernild, S.H., B. Hashold and G.E. Liston. 2008. Climatic control on river discharge simulations, Zackenberg River drainage basin, northeast Greenland. Hydrol. Process., 22(12), 1932-1948.

Moore, R.D. and 7 others. 2009. Glacier change in western North America: influences on hydrology, geomorphic hazards and water quality. Hydrol. Process., 23(1), 42-61.

Ng, F., S. Liu, B. Mavlyudov and Y. Wang. 2007. Climatic control on the peak discharge of glacier outburst floods. Geophys. Res. Lett., 34(21), L21503. (10.1029/2007GL031426.)

Parker, D.E. and E.B. Horton. 1999. Global and regional climate in 1998. Weather, 54(6), 173-184.

$\mathrm{Pu}$, J. ed. 1994. Glacier inventory of China VIII. The Changjiang (Yangtze) River drainage basin. Lanzhou, Gansu Culture Publishing house. Academia Sinica. Lanzhou Institute of Glaciology and Geocryology. [In Chinese.\}

Richardson, S.D. and J.M. Reynolds. 2000. An overview of glacial hazards in the Himalayas. Quat. Int., 65/66(1), 31-47.

Ruiz, D., H.A. Moreno, M.E. Gutierrez and P.A. Zapata. 2008. Changing climate and endangered high mountain ecosystems in Colombia. Sci. Total Environ., 398(1), 122-132.

Shangguan, D., S. Liu, Y. Ding, Y. Zhang, E. Du and Z. Wu. 2008. Correspondence. Thinning and retreat of Xiao Dongkemadi glacier, Tibetan Plateau, since 1993. J. Glaciol., 54(188), 949-951.

Shen, Z., Z. Lui and J. Fank. 2004. Altitudinal changes in species diversity and community structure of Abies fabri communities at Hailuo Valley of Mt. Gongga, Sichuan. [Biodiversity Sci.], 12(2), 237-244. [In Chinese with English summary.] 
Shi, Y. and S. Liu. 2000. Estimation on the response of glaciers in China to the global warming in the 21st century. [Chinese Sci. Bull.], 45(7), 668-672. [In Chinese.]

Shi, Y. and X.S. Zhang. 1995. Impact of climate change on surface water resource and tendency in the future in the arid zone of northwestern China. Sci. China, 38(11), 1395-1408.

Shi, Y., S. Liu, B. Ye, C. Liu and Z. Wang, eds. 2008. Concise glacier inventory of China. Shanghai, Shanghai Popular Science Press.

Stoffel, M. and M. Beniston. 2006. On the incidence of debris flows from the early Little Ice Age to a future greenhouse climate: a case study from the Swiss Alps. Geophys. Res. Lett., 33(16), L16404. (10.1029/2006GL026805.)

Su, Z. and Y. Shi. 2000. Response of monsoonal temperate glaciers in China to global warming since the Little Ice Age. J. Glaciol. Geocryol., 22(3), 223-229. [In Chinese with English summary.]

$\mathrm{Su}, \mathrm{Z}$. and Y. Shi. 2002. Response of monsoonal temperate glaciers to global warming since the Little Ice Age. Quat. Int., 97/98, 123-131.

Su, Z., S. Liu, N. Wang and A. Shi. 1994. Studies of recent fluctuations of glacier length in the Gongga Mountain. In Xie, Z. and V.M. Kotlyakov, eds. Glaciers and environment in the Qinghai-Xizang (Tibet) Plateau (I) - the Gongga Mountain: reports on the Sino-Russian Joint Glaciological Expedition. Beijing and New York, Science Press, 165-173.

$\mathrm{Su}, \mathrm{Z}$., G. Song and Z. Cao. 1996. Maritime characteristics of Hailuogou Glacier in the Gongga Mountains. J. Glaciol. Geocryol., 18, Special Issue, 51-59. [In Chinese with English summary.]

Xie, Z., Z. Su, Y. Shen and Q. Feng. 2001. Mass balance and water exchange of Hailuoguo glacier in Mount Gongga and their influence on glacial melt runoff. J. Glaciol. Geocryol., 23(1), 7-15. [In Chinese with English summary.]

Yao, T.D., Y.Q. Wang, S.Y. Liu, J.C. Pu, Y.P. Shen and A.X. Lu. 2004. Recent glacial retreat in High Asia in China and its impact on water resource in Northwest China. Sci. China D, 47(12), 1065-1075.

Zhang, W., Z. Su and T. Li. 2001. Dynamic features of glacier in the Hailuogou. In Zhong, X.H., ed. Environment and ecosystem in the eastern edge of Qinghai-Xizang Plateau. Chengdu, Sichuan University Press, 81-101. [In Chinese with English summary.]

Zhang, Y., K. Fujita, S. Liu, Q. Liu and X. Wang. 2010. Multidecadal ice-velocity and elevation changes of a monsoonal maritime glacier: Hailuogou glacier, China. J. Glaciol., 56(195), 65-74. 